\title{
Cell Density-Dependent Stabilization of Calf Thymocyte Viability In Vitro as Mediated by a Self-Released Macromolecular Factor
}

\author{
G.A. Rockwell and Atuhiro Sibatani \\ CSIRO Genetics Research Laboratories-North Ryde, Unit of Molecular and \\ Cellular Biology, P.O. Box 90 Epping, N.S.W. 2121, Australia
}

\begin{abstract}
Calf thymocytes, freshly suspended in a protein-free minimum essential medium quickly lost viability at $3 \times 10^{5}$ but not at $1 \times 10^{7}$ cells $/ \mathrm{ml}$. For technical reasons $\left[{ }^{3} \mathrm{H}\right]$ thymidine incorporation into DNA was routinely used as a relative index of cell viability. The non-dialyzable fraction of a conditioned medium and of a cell-free extract obtained from thymocytes reversed the loss of viability at lower population density. An effective assay system was devised aiming at the isolation of the active factor. Calf serum and simple proteins like serum albumin and cytochrome $c$ were without effect, and the former did not affect the activity of the factor. However, the factor was not highly species- or organ-specific. The abundance of the factor in thymocytes seemed to vary much less than the responsiveness to the factor of thymocytes from different animals.
\end{abstract}

One of us (6) reported that the incorporation of labelled thymidine into DNA of calf thymocytes in primary culture progressively decreased when the population density of thymocytes was lowered from $1 \times 10^{7}$ to $3 \times 10^{5}$ cells $/ \mathrm{ml}$. This decrease was reversed by a non-dialyzable material released by the cells. These observations were interpreted to indicate a density dependence of cell growth in thymocyte populations mediated by a self-released factor similar to the protein isolated from the cell surface of cultured embryonic fibroblasts (1). We now wish to report that the reduction of thymidine incorporation observed with thymocyte suspensions at lower cell densities is due to cell lysis, and that a fraction from conditioned medium (CM) or cell-free extract prepared from thymocytes prevents such a cellular death. The active factor seems to be a protein playing some essential role in the maintenance and interaction of thymocytes in vitro. A preliminary report of this paper has appeared (7).

\section{MATERIALS AND METHODS}

Calf thymocytes were isolated in Hanks solution and suspended in Eagle's Minimum Essential Medium (MEM; F-15, Grand Island Biological Co., Grand Island, N.Y.) with 100 $\mu \mathrm{g}$ streptomycin and 100 units of penicillin per ml (F15PS) as described previously (6). Routinely $2-\mathrm{ml} \mathrm{samples}$ of suspensions were incubated at $37^{\circ} \mathrm{C}$ at two standard cell densities, high $\left(1 \times 10^{7} \mathrm{cells} / \mathrm{ml}\right)$ and low $\left(3 \times 10^{5}\right.$ cells $\left./ \mathrm{ml}\right)$. When necessary, damaged cells were removed by filtering cell suspensions in a medium of low ionic strength (LIS) through cotton wool (8), Hanks solution being used for the iso-osmotic buffered balanced salt solution (IBBS) for preparing the LIS medium (8). The viable cells were collected and washed in Hanks solution by centrifuging at $450 \times \mathrm{g}$ for $4.5 \mathrm{~min}$ and resuspended in F15PS. 
For preparation of CM, a thymocyte suspension of $5 \times 10^{8}$ cells $/ \mathrm{ml}$ in F15PS was incubated for $1.5 \mathrm{~h}$ at $37^{\circ} \mathrm{C}$, centrifuged for $10 \mathrm{~min}$ at $600 \times \mathrm{g}$, and the supernatant filtered through a Whatman glass filter disc GF/C. To prepare cell extracts, $5-30 \mathrm{ml}$ of thymocyte suspensions in Hanks solution at $5-10 \times 10^{8}$ cells $/ \mathrm{ml}$ were homogenized in an ice-chilled container of a Nippon Seiki (Tokyo) Homogenizer at top speed for $5 \mathrm{~min}$. The homogenate was centrifuged at $10,000 \times \mathrm{g}$ for $15 \mathrm{~min}$ and the supernatant filtered as with $\mathrm{CM}$. The filtered $\mathrm{CM}$ or extract was usually dialyzed overnight against Hanks solution or F15PS.

For trypan blue exclusion of viable cells, $0.8 \mathrm{ml}$ of cell suspension was mixed with $0.1 \mathrm{ml}$ of calf serum and $0.1 \mathrm{ml}$ of $1 \%$ trypan blue solution in saline. For determining the extent of ${ }^{51} \mathrm{Cr}$ release as a measure of cell lysis (9), thymocytes were freshly suspended at $1 \times 10^{8} \mathrm{cells} / \mathrm{ml}$ in $\mathrm{F} 15 \mathrm{PS}$, and $10 \mathrm{ml}$ of the suspension was mixed with $0.6 \mathrm{ml}$ of $1 \mathrm{mCi} / \mathrm{ml}\left[{ }^{51} \mathrm{Cr}\right]$ sodium chromate $\left(0.12 \mathrm{mCi} / \mu \mathrm{g} \mathrm{Cr}\right.$, Amersham) in saline and incubated at $37^{\circ} \mathrm{C}$ for $30 \mathrm{~min}$. The cells were washed in $10 \mathrm{ml}$ F15PS three times, suspended at the desired densities and incubated at $37^{\circ} \mathrm{C}$ in $2-\mathrm{ml}$ samples. At intervals duplicate samples were centrifuged at $600 \times \mathrm{g}$ for $5 \mathrm{~min}$ and 1-ml samples of the supernatnat were counted in a Packard Auto-Gamma Scintillation Spectrometer. Recovery of the total radioactivity from the incubated samples prior to centrifugation was around $100 \%$. We also estimated the extent of cell lysis in a Coulter counter.

For thymidine incorporation, we used the method described previously (6) with the following modifications: 2-ml samples in triplicate were mixed with $10 \mu \mathrm{l}$ of aqueous solution of [methyl- ${ }^{3} \mathrm{H}$ ]thymidine (Amersham) of either (a) $1 \mathrm{mCi} / \mathrm{ml}$ and $5 \mathrm{Ci} / \mathrm{mmole}$, for a 10 -min pulse at intervals; or (b) $200 \mu \mathrm{Ci} / \mathrm{ml}$ and $1 \mathrm{Ci} / \mathrm{mmole}$, for a 2 -h period between $3-5$ or $4-6$ hours of culture. At the end of the labelling period, the suspensions were chilled in ice, and mixed (a) with $1 \mathrm{ml}$ of $1.4 \%$ sodium dedecyl sulphate (SDS) and $1 \mathrm{ml}$ of Hanks solution containing 50 $\mu \mathrm{g} / \mathrm{ml}$ each of unlabelled thymidine and calf thymus DNA; or (b) with $1 \mathrm{ml}$ of $1.4 \%$ SDS containing $50 \mu \mathrm{g} / \mathrm{ml}$ of unlabelled thymidine and $1 \mathrm{ml}$ of thymocyte suspensions containing $2 \times 10^{7}$ cells for the low- and $6 \times 10^{5}$ cells for the high-density samples. They were then heated for $10 \mathrm{~min}$ at $60^{\circ} \mathrm{C}$, chilled in ice, mixed with $1 \mathrm{ml}$ of a mixture containing $50 \%$ trichloroacetic acid and $25 \%$ acetone and frozen. After thawing the precipitate was filtered on a Whatman glass filter disc (FG/C), dissolved in $2 \mathrm{ml}$ of NCS (Nuclear Chicago) and $0.3 \mathrm{ml}$ of water and counted as described previously (5). Means and standard deviations of the incorporated radioactivity are given in $\mathrm{dpm} / 10^{3}$ cells.

For gel filtration of the active principle, $1 \mathrm{ml}$ of extract was passed through a $1.5 \times 8 \mathrm{~cm}$ column of Sephadex G-25 equilibrated with Hanks salt solution (HSS); or $10 \mathrm{ml}$ of the extract through a $3.3 \times 33 \mathrm{~cm}$ column of Ultrogel ACA 34 (LKB) equilibrated with HSS without bicarbonate (HSS-B), and the portion eluted between 90 and $120 \mathrm{ml}$, corresponding to around 200,000 daltons, was used as the active fraction.

For binding to nitrocellulose discs of the active principle, $6 \mathrm{ml}$ of the above fraction was passed slowly through a double layer of filter discs (Sartorius Membranefilter SM $0.45 \mu$ pore size and $5 \mathrm{~cm}$ diameter) soaked and washed in HSS-B. The protein concentration of the filtrate dropped from the original 180 down to $12 \mu \mathrm{g} / \mathrm{ml}$. The Lowry method was used for protein determination with bovine serum albumin fraction $\mathrm{V}$ as the standard.

\section{RESULTS}

With a large number of thymocyte samples at the low cell density, assessing the loss of viable cells by the dye exclusion method was not practical. We therefore monitored cell lysis by ${ }^{51} \mathrm{Cr}$ release (9) and by total cell counts during primary culture of thymoctyes in a protein-free MEM with or without the addition of CM. By the end of 2-h incubation, the ${ }^{51} \mathrm{Cr}$-labelled cells had released a major fraction of radioactivity at a density of $3 \times 10^{5}$ cells $/ \mathrm{ml}$ in the absence of $\mathrm{CM}$ but not in its presence nor at $1 \times 10^{7}$ 


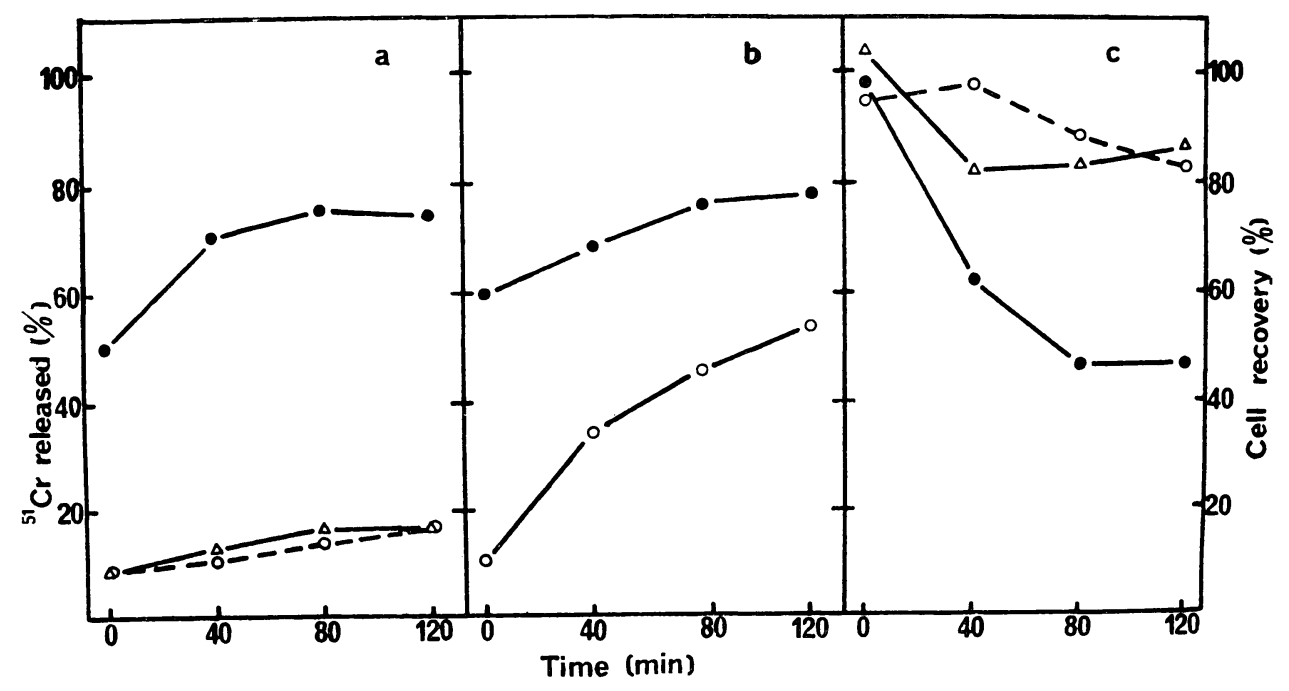

Fig. 1. Lysis of calf thymocytes at low density and its prevention by CM. (a, b) The extent of cell lysis was estimated by ${ }^{51} \mathrm{Cr}$ release: (a) $(\triangle) 1 \times 10^{7}$ cells $/ \mathrm{ml},(\bullet) 3 \times 10^{5}$ cells $/ \mathrm{ml},(\circ) 3 \times 10^{5}$ cells $/ \mathrm{ml}$ with $\mathrm{CM}$ added to $100 \mu \mathrm{g}$ protein $/ \mathrm{ml}$ at the outset of incubation; the proportion of ${ }^{51} \mathrm{Cr}$ release from cells frozen and thawed three times was around $60 \%$ for both cell densities. (b) ( $\bullet$ ) $3 \times 10^{5} \mathrm{cells} / \mathrm{ml}$ as in (a), ( $\circ$ ) the same but receiving $0.2 \mathrm{ml}$ of $\mathrm{CM}$ with a protein concentration of $1.1 \mathrm{mg} / \mathrm{ml}$ at the end of incubation and just prior to centrifuging. (c) Cell loss from suspension was measured with a Coulter counter; duplicate cell counts were made for each of the duplicate samples. Same symbols as in (a).

cells/ml (Fig. la). In the first case we overestimated the ${ }^{51} \mathrm{Cr}$ release, because the addition of CM to the low-density cell suspension, immediately before centrifuging to separate the cells from the CM-free incubation medium, significantly reduced the ${ }^{51} \mathrm{Cr}$ release, indicating that some weakened cells may have been lyzed during centrifuging (Fig. lb). When corrected for this error, the results with ${ }^{51} \mathrm{Cr}$ were in harmony with those of the direct cell counts (Fig. lc), indicating that the cells gradually lost viability when incubated at the low density. We also observed that the viability of cells as estimated by ${ }^{51} \mathrm{Cr}$ release, like thymidine incorporation (6), progressively decreased as the cell density was lowered from $1 \times 10^{7}$ cells $/ \mathrm{ml}$ to various lower levels. We thus conclude that the previous results (6) which revealed a decrease in the incorporation of labelled thymidine, uridine and amino acids into cellular constituents at the lower cell density reflect cell lysis rather than a depression of macromolecular synthesis in live cells, and that this cell lysis can be prevented from occurring by some active component in CM.

However, both of these methods suffered some of the following disadvantages: limited numerical latitude for various experimental values, relatively high backgrounds, or a limited number of samples which could be handled during a brief period of time. In these respects, the incorporation of $\left[{ }^{3} \mathrm{H}\right]$ thymidine was convenient. One of us (6) showed the validity of thymidine incorporation as a measure of DNA synthesis in this system. In what follows, however, we will use it as a relative index of cell viability rather than that of DNA-synthetic activity of a given cell population. Also, for the reason to be explained later, we will use CM and extract of thymocytes in- 
TABLE 1. COMPARISON OF THE STABILITY OF THYMOCYTES AT HIGH AND LOW DENSITY BEFORE AND AFTER REMOVAL OF DAMAGED CELLS $a$

\begin{tabular}{|c|c|c|c|}
\hline & \multirow{2}{*}{$\begin{array}{l}\text { Proportion of } \\
\text { viable cells }\end{array}$} & \multicolumn{2}{|c|}{$\mathrm{Dpm} / 10^{3}$ cells incubation } \\
\hline & & $3 \times 10^{5}$ cells $/ \mathrm{ml}$ & $1 \times 10^{7}$ cells $/ \mathrm{ml}$ \\
\hline \multicolumn{4}{|l|}{ Experiment 1} \\
\hline Original cell suspension & 0.62 & $1.00 \pm 0.22$ & $20.3 \pm 0.9$ \\
\hline Viable cell suspension $b$ & 0.98 & $0.46 \pm 0.16$ & $24.9 \pm 1.5$ \\
\hline \multicolumn{4}{|l|}{ Experiment 2} \\
\hline Original cell suspension & & $1.20 \pm 0.42$ & $13.2 \pm 1.2$ \\
\hline Viable cell suspension & & $0.93 \pm 0.32$ & $12.0 \pm 0.8$ \\
\hline
\end{tabular}
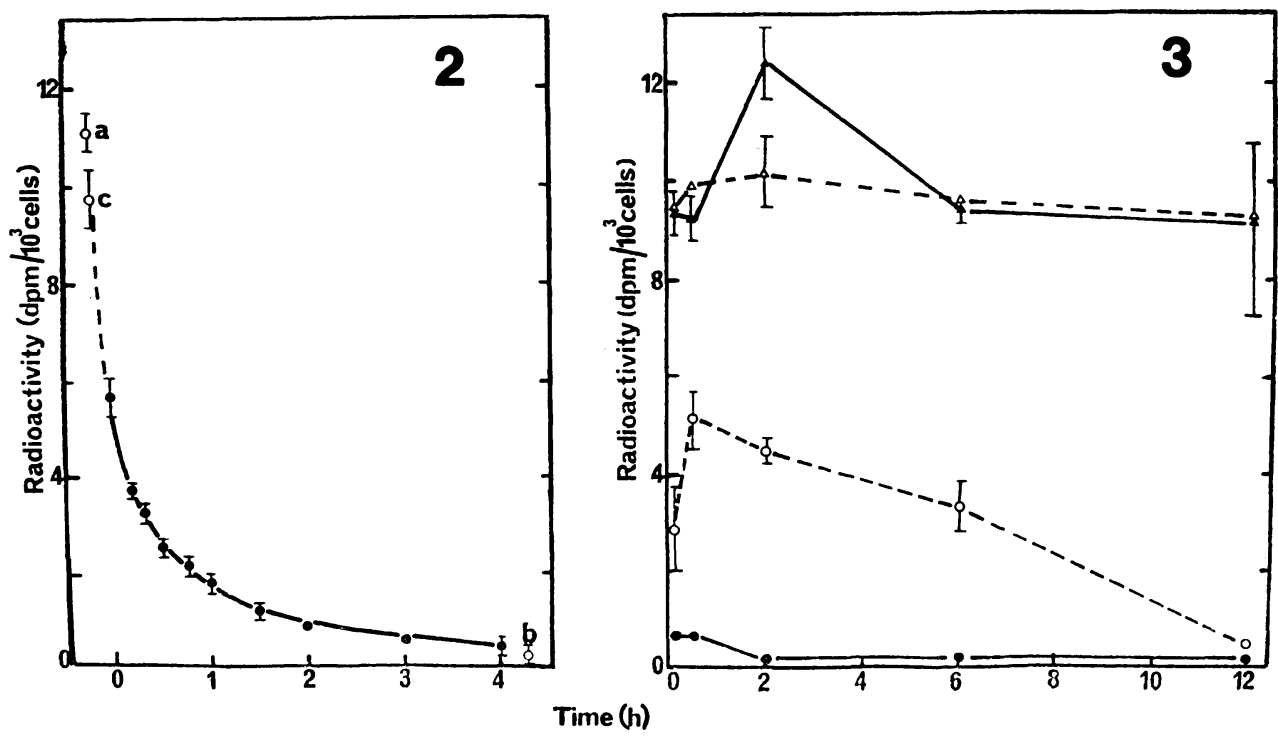

Fig. 2. Progressive death of thymocytes during incubation at the low cell density as estimated by the decline of their responsiveness to the cell stabilizing activity of thymocyte extract. Samples $(2 \mathrm{ml})$ of a thymocyte suspension at $3 \times 10^{5}$ cells $/ \mathrm{ml}$ received $0.1 \mathrm{ml}$ of thymocyte extract with a protein concentration of $1.05 \mathrm{mg} / \mathrm{ml}$ at indicated times after the onset of incubation $(\bullet)$. Controls $(\circ)$ : (a) $1 \times 10^{7}$ cells $/ \mathrm{ml}$, no addition; (b) $3 \times 10^{5} \mathrm{cells} / \mathrm{ml}$, no addition; (c) $3 \times 10^{5} \mathrm{cells} / \mathrm{ml}$, the dilution being made directly into an F15PS containing cell extract sufficient to produce the same final protein concentration; co-ordinates on abscissa for (a) and (b) are arbitrary, while (c) is plotted 13 min prior to $0 \mathrm{~h}$, which was the length of time elapsed between the dilution of cells in plain F15PS at room temperature and the first addition of the extract which was recorded as $0 \mathrm{~h}$; incubation of all the samples at $37^{\circ} \mathrm{C}$ followed immediately. $\left[{ }^{3} \mathrm{H}\right]$ thymidine incorporation was measured during $4-6 \mathrm{~h}$ of incubation.

Fig. 3. Death of thymocytes at the low density and their protection by CM during a primary culture as measured by $\left[{ }^{3} \mathrm{H}\right]$ thymidine incorporation during 10 -min pulse. $(\bullet, \circ) 3 \times 10^{5} \mathrm{cells} / \mathrm{ml} ;(\Delta, \Delta)$ $1 \times 10^{7} \mathrm{cells} / \mathrm{ml} ;(\bullet, \Delta)$ no addition; $(\circ, \triangle)$ with $\mathrm{CM}$ added to $35 \mu \mathrm{g}$ protein $/ \mathrm{ml}$ at the outset of incubation. 
terchangeably as the source of the cell-stabilizing activity.

Ordinary preparations of thymocytes contained about $60-70 \%$ viable cells, well within the range reported for mouse thymocytes (1). However, when damaged cells were removed, the overall results did not change; even a more pronounced difference emerged between the high- and low-density samples, with respect to $\left[{ }^{3} \mathrm{H}\right]$ thymidine incorporation (Table 1).

Fig. 2 shows how a delay in the addition of a thymocyte extract to a low-density cell suspension led to the progressive loss of its responsiveness to the active principle, as measured by thymidine incorporation during 4-6 $\mathrm{h}$ of incubation. This again indicates that cells gradually died while being incubated at $3 \times 10^{5}$ cells $/ \mathrm{ml}$ in a protein-free medium. As expected, the responsiveness of the cells was least affected when a suspension at the high density was diluted directly into a medium containing the extract to obtain the low cell density. But when diluted first into a protein-free medium, the responsiveness of the cells was quickly curtailed.

Fig. 3 indicates that, when tested by $\left[{ }^{3} \mathrm{H}\right]$ thymidine incorporation for $10 \mathrm{~min}$, cells
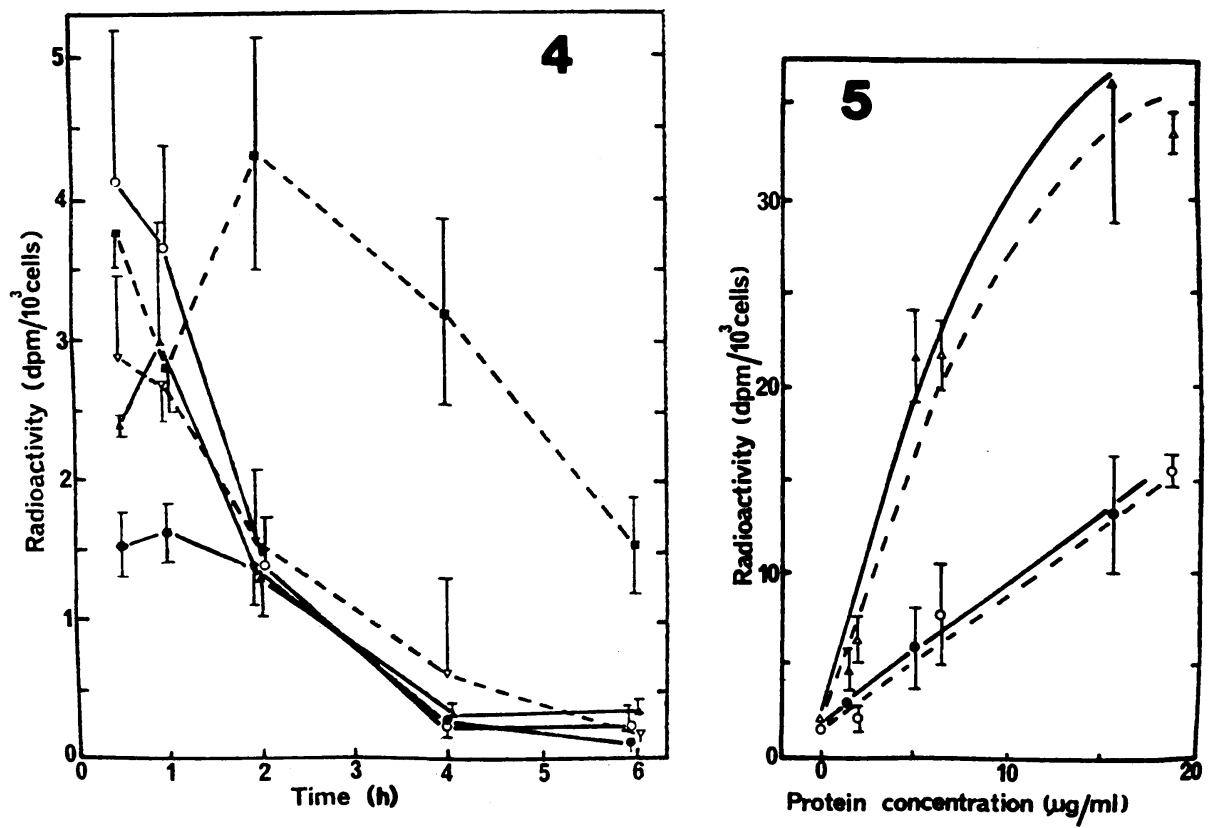

Fig. 4. Specificity of the factor in preventing the death of calf thymocytes at the low density as measured by thymidine incorporation. Cell suspension at $3 \times 10^{5}$ cells $/ \mathrm{ml}$ were pulse-labelled at indicated times for $10 \mathrm{~min}$ with $\left[{ }^{3} \mathrm{H}\right]$ thymdine. (•) No addition; ( $\bullet$ ) with $\mathrm{CM}$ added to $50 \mu \mathrm{g}$ protein/ $\mathrm{ml}$; ( $)$ ) with calf serum added to $500 \mu \mathrm{g}$ protein $/ \mathrm{ml} ;(\nabla)$ with bovine serum albumin added to $50 \mu \mathrm{g} /$ $\mathrm{ml} ;$ ( $\Delta$ ) with cytochrome c added to $50 \mu \mathrm{g} / \mathrm{ml}$.

Fig. 5. Autologous and heterologous combination of thymocytes and preparations of the factor derived from them. Parallel thymocyte suspensions prepared from two calf thymuses (1 and 2) served for preparing the cell extracts and the bioassay system. The extract was prepared from a part of the suspension at $5 \times 10^{5}$ cells $/ \mathrm{ml}$ and further processed, while the bulk of the suspension stood in ice until immediately before use for assay. The Sephadex G-25 exclusion peaks of the extracts were diluted with F15PS and added to the cell suspension at $3 \times 10^{5} \mathrm{cells} / \mathrm{ml}$. Thymidine incorporation was measured during $4-6 \mathrm{~h}$ of incubation. $(\bullet, \circ)$ Cells from thymus $1 ;(\bullet, \Delta)$ cells from thymus $2 ;(\bullet, \Delta)$ extracts from thymus $1 ;(\circ, \Delta)$ extracts from thymus 2 . 
at the high density survived well during the first $12 \mathrm{~h}$ of primary culture while the effect of CM on cell viability at the low density gradually declined. This decline may have been due to a decay of the active component in the CM initially added to the medium, but this point has not yet been pursued further. The early peak of incorporation noticeable for the higher density suspension without CM was reproducible but we have at present no explanation for it. Except for this point, CM had no significant effect on cells at the high density.

The experiment illustrated in Fig. 4 revealed that calf serum, serum albumin and cytochrome $c$ enhanced the $\left[{ }^{3} \mathrm{H}\right]$ thymidine incorporation at the lower density during the first hour of incubation. Some other proteins, including myoglobin, ovalbumin, lysozyme and bacterial penicillinase were not as active. But all these non-specific effects soon disappeared to leave the more specific effects of $\mathrm{CM}$ clearly discernible at $2-6 \mathrm{~h}$ of incubation; hence our choice of $\left[{ }^{3} \mathrm{H}\right]$ thymidine incorporation during 3-5 or 4-6 hours of incubation for routine assay of cell-stabilizing activity.

We confirmed the absence of any activity in calf serum as indicated in Fig. 4 in further experiments summarized in Fig. 6. Thus, calf serum neither protected cells at the low density nor affected the action of $\mathrm{CM}$ when 10 times as much serum protein was present in the medium as that contributed by the added CM. Fig. 6 includes an experiment demonstrating that a crude extract of washed thymocytes also contained the active principle for thymocyte stabilization at the low density. In a separate experiment we observed that the cell extract contained about 10 times as much active material per cell as $\mathrm{CM}$ but the activity per unit amount of protein was comparable for extract and CM.

At higher protein concentration, both $\mathrm{CM}$ and cell extract depressed thymidine incorporation. This trend was more conspicuous with the extract than with CM (Fig. 6). By gel filtration the active principle was at least partially resolved from a macromolecular inhibitor of thymidine incorporation (Rockwell and Sibatani, unpublished). We used the initial slope of the dose-response curve as exemplified by Fig. 6 , curves $a, e$ and $f$ as a measure of the thymocyte-stabilizing activity. The effective protein concentration range for $\mathrm{CM}$ and crude extract as shown in Fig. 6 corresponded to the addition of serum to $0.01-0.05 \%$ and became much lower than that upon concentrating the active principle. These observations indicated the presence of a specific component (or components) for stabilization of thymocytes in vitro. The active component was bound on a nitrocellulose membrane filter (2) (Fig. 7), and lost its activity completely upon heating at $95^{\circ} \mathrm{C}$ for $10 \mathrm{~min}$, indicating that it is a protein. The observations as well as the gel filtration experiments mentioned above showed that low molecular-weight metabolites were not involved in the stabilization of viability. Unlike the self-released growth enhancing protein of fibroblasts (1), calcium ions were not effective in fractionation of the activity.

The experiment shown in Fig. 5 indicates that autologous and heterologous cell extracts were equally active for a thymocyte population. Fig. 5 also reveals that the cell's responsiveness to the active principle varied considerably from thymus to thymus, but that the abundance of the active factor in the cell did not vary. We have repeatedly confirmed this last point with different thymocyte extracts.

Preliminary experiments using mouse and rabbit thymocyte extracts indicated that the cell-stabilizing factor effective on calf thymocytes was not species-specific, and that various calf tissues contained similar activities to lesser extents, with the excep- 


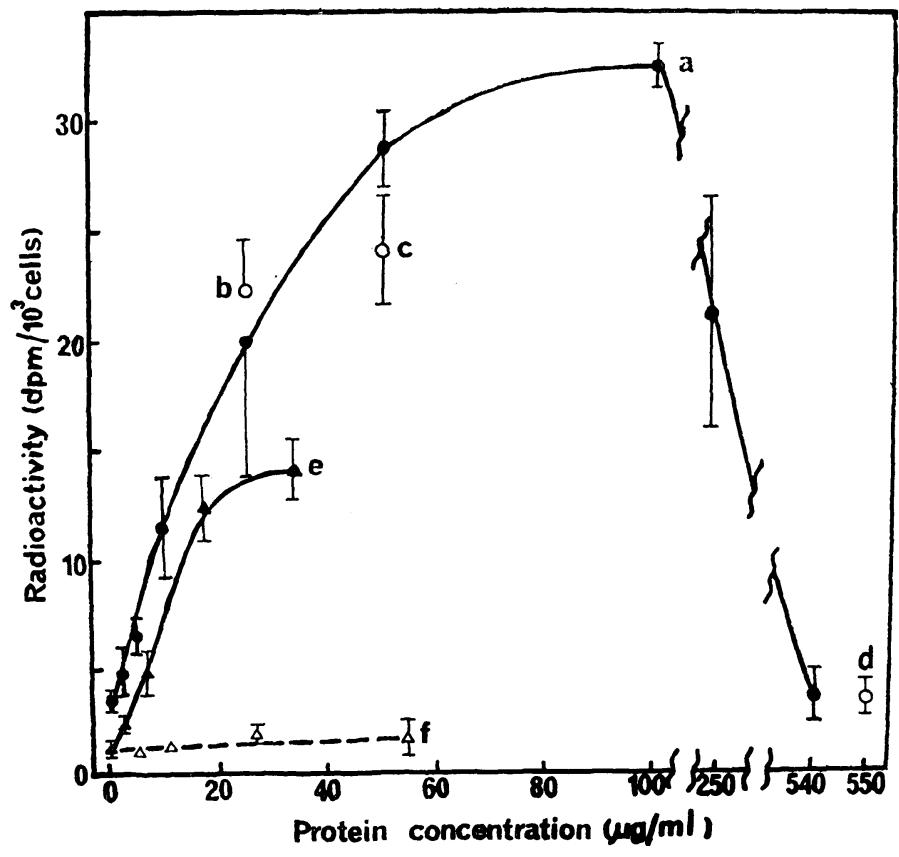

Fig. 6. Prevention of cell death in a calf thymocyte population at $3 \times 10^{5}$ cells $/ \mathrm{ml}$, measured by thymidine incorporation during 4-6 h of incubation, as a function of the concentration of proteins added of CM, extract of thymocytes and calf serum. (a)-(c) with CM; (b) and (c) in the presence of whole calf serum added to 275 and $550 \mu \mathrm{g}$ protein $/ \mathrm{ml}$, respectively; (d) the same cell suspension as used for (a)-(c) with calf serum; (e) another cell suspension with thymocyte extract; (f) the same cell suspension as used for (e) with calf serum dialyzed as the thymocyte extract.

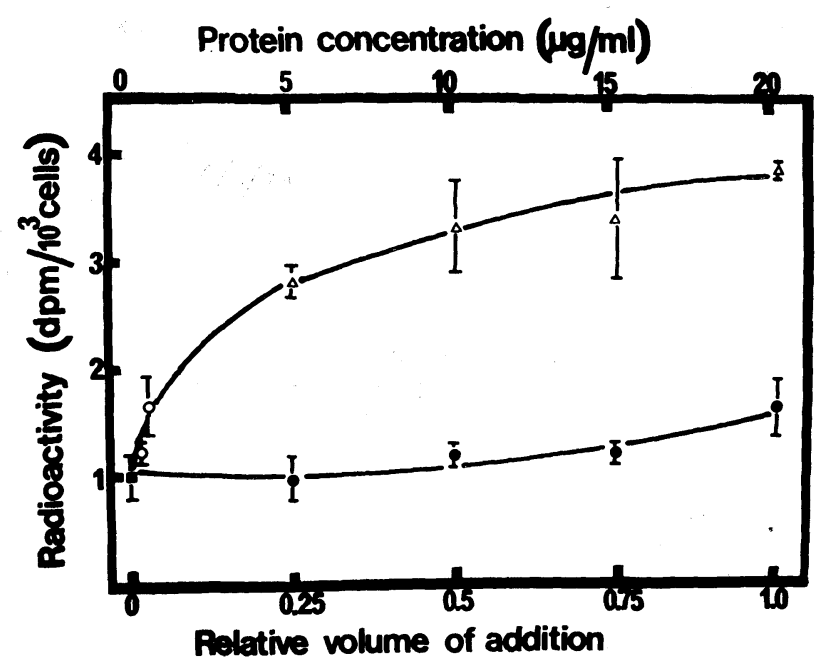

Fig. 7. Binding of the thymocyte-stabilizing activity to nitrocellulose disc. The active fraction of a thymocyte extract obtained by Ultrogel filtration and its filtrate through nitrocellulose discs were similarly diluted with F15PS to various extents and added to the cell suspension of a final cell density of $3 \times 10^{5}$ cells $/ \mathrm{ml}$. $\left[{ }^{3} \mathrm{H}\right]$ thymidine incorporation was measured during $3-5 \mathrm{~h}$ of incubation. $\triangle$, Original active fraction from Ultrogel column; $\bullet, \circ$, nitrocellulose filtrate $(\bullet$, volumes added; $\odot$, concentrations of protein). 
tion of submaxillary gland which yielded as much activity as thymocytes. In a relative scale, the activities per $\mu \mathrm{g}$ protein of the extract were thymocyte 1: submaxillary gland $1.10 \pm 0.14$ : parotid gland $0.75 \pm 0.04$ : cerebrum $0.36 \pm 0.06$ : liver $0.30 \pm 0.06$ : muscle $0.20 \pm 0.06$.

\section{DISCUSSION}

Most thymocytes are believed to live for only 3-4 days in situ (3). This natural short life span appears to be the reason why one can not keep them alive in vitro indefinitely. However, under optimal conditions the viability of these cells, or their DNA-synthesizing ability, declined only slightly during the first $12 \mathrm{~h}$ of primary culture, once they had passed the initial 2-h period. During this time the rate of thymidine incorporation rose temporarily at the high density, and serum and certain proteins had some temporary protective effect on the cells at the low density. The meaning of these observations remains obscure, but we feel that, after the early period of possible adjustment to a new environment, the cell's behaviour in vitro may reflect some facets of their physiological endowment. Therefore, the fact that cells require a certain specific protein-like material at a relatively low concentration for their stabilization in vitro suggests its significance in cellular function. Interestingly, one and the same thymocyte population contains the donor and recipient cells of this active factor, suggesting interaction of cells. However, the question as to whether it is actually synthesized in the thymocyte remains to be answered. A thymocyte population is heterogeneous (4). Relevant to this point is our finding that the abundance of the active factor varied little among thymocyte preparations derived from different animals but the responsiveness to a given preparation of the active factor was highly variable among thymocytes from different animals. Similar activity was also found in a number of other calf tissues, but curiously missing in serum. We are now trying to isolate the active principle to explore further aspects of these problems.

Acknowledgments. We thank Dr K. Shortman, Walter and Eliza Hall Institute for Medical Research, Melbourne, for his advice on processing thymocytes, Dr A.H. Reisner of the Division of Animal Production at our laboratories for his help in automation of data reduction, and Mr J.F. Kelly for his skillful technical assistance.

\section{REFERENCES}

1. IgARASHI, Y. and Y. YAOI. Growth-enhancing protein obtained from cell surface of cultured fibroblasts. Nature (Lond.) 254, 248-250, 1975

2. Kihara, H.K. and H. Kuno. Microassay of protein with nitrocellulose membrane filters. Anal. Biochem. 24, 96-105, 1968

3. Metcalf, D. Functional interaction between the thymus and other organs. In The Thymus, ed. Defendi, V. and D. Metcalf, Wistar Institute Press, Philadelphia, pp. 53-72, 1964

4. Shortman, K. and H. Jackson. The differentiation of T lymphocytes: I. Proliferation kinetics and interrelationships of subpopulations of mouse thymus cells. Cell. Immunol. 12, 230-246, 1974

5. Sibatani, A. Precipitation and counting of minute quantities of labeled nucleic acids as cetyltrimethylammonium salt. Anal. Biochem. 33, 279-285, 1970

6. Sibatani, A. Reduction of DNA synthesis in calf thymocytes at lower cell densities and its reversal by diffusible macromolecules released by these cells. Biochim. Biophys. Acta 294, 57-73, 1973 
7. Sibatani, A. and G.A. Rockwell. A density-dependent self-stabilization of calf thymocyte populations in vitro through a diffusible macromolecule. J. Cell Biol. 70, 204a, 1976

8. Von Boehmer, H. and K. Shortman. The separation of different cell classes from lymphoid organs. IX. A simple and rapid method for removal of damaged cells from lymphoid cell suspensions. J. Immunol. Methods 2, 293-301, 1973

9. Wigzell, H. Quantitative titrations of mouse $\mathrm{H}-2$ antibodies using $\mathrm{Cr}^{51}$-labelled target cells. Transplantation (Baltimore) 3, 423-431, 1965

(Received for publication, January 11, 1977) 